\title{
Potential ecological and epidemiological factors affecting the persistence of classical swine fever in wild boar Sus scrofa populations
}

\author{
S. KRAMER-SCHADT*, N. FERNÁNDEZ*† and H.-H. THULKE* \\ *UFZ, Helmholtz Centre for Environmental Research - UFZ, Department of Ecological \\ Modelling (OESA), Permoserstr. 15, D-04318 Leipzig, Germany, †Department of Applied \\ Biology, Estación Biológica de Doñana, Consejo Superior de Investigaciones Científicas, \\ Avenida Maria Luisa s/n, E-41013 Sevilla, Spain
}

\begin{abstract}
1. Classical swine fever has increased in economic importance since it has become endemic in some wild boar Sus scrofa populations in Europe. The mechanism of disease persistence is still not well understood, and several aspects of both the ecology of boar and the virus are claimed to be responsible for disease persistence.

2. We review literature on the spread and persistence of the disease in free-ranging wild boar. We determine whether the available knowledge can explain the observed patterns via mechanistic processes and their interactions, and assemble knowledge in a conceptual model.

3. We speculate that the most important factor explaining disease persistence is an alteration in disease outcome, resulting in individual courses with prolonged infectiousness or a sustained reproductive population through immunity. This effect is reinforced by high wild boar numbers either within sites or scattered over larger areas.

4. We highlight the sparse knowledge of disease transmission between wild boar. We derive management suggestions for different phases of an outbreak based on the conceptual model and advocate the use of model-based investigations to test alternative management options.
\end{abstract}

Keywords: disease course, disease cycling, disease management, epidemiology, host-virus system, wildlife

\section{INTRODUCTION}

Classical swine fever (CSF) is a major concern for animal welfare and is an economic threat in many nations worldwide. The disease is caused by a pestivirus (CSFV) affecting all members of the Suidae (domestic pigs and conspecific wild boar Sus scrofa, Moennig et al., 1999). Due to the high contagiousness of the infection and the legally mandatory preventive measures, CSF outbreaks result in dramatic economic losses. For example, the total direct costs in The Netherlands during the CSF epidemic in 1997 amounted to US\$2.3 billion, and more than 11 million domestic pigs had to be destroyed (Meuwissen et al., 1999).

Cross-infections between wild boar and domestic pigs are a primary cause of CSF outbreaks in farmed and free-living populations. Domestic pigs are infected due to direct contact (Laddomada et al., 1994; Biagetti, Greiser-Wilke \& Rutili, 2001; Zanardi et al., 2003), or indirect contact via feeding of contaminated wild boar meat to domestic pigs (Laddomada, 
2000). Up to $60 \%$ of all CSF outbreaks in domestic pigs in Germany can be attributed to infected wild boar and wild boar meat (Fritzemeier et al., 2000). But reinfection via domestic pigs, or via swill-feeding to wild boar, is also reported (Artois et al., 2002; Paton \& GreiserWilke, 2003).

In areas where CSF cycles in wild boar populations, the constant threat to the pig industry requires an effective management strategy. So far, it is unclear why CSF persists in some local populations (Fritzemeier et al., 2000). Here, persistence refers to the recurrence of the infection after the first major epidemic outbreak (Swinton et al., 2002; Lloyd-Smith et al., 2005). Generally, persistence in natural populations is explained by the bridging of time necessary to replenish susceptibles via birth, immigration or loss of protective immunity. The long-term infectiousness of many viruses allow the bridging of this time gap. Carrier-states (Lenghaus et al., 1994), as with the feline immunodeficiency virus (Courchamp et al., 1995), can induce lifelong infectivity in the host. The Herpes simplex virus remain dormant in once-infected hosts and, upon reactivation, cause such hosts to become infectious (Mollema, de Jong \& Van Boven, 2005). Viral coevolution towards lower virulence was found responsible for long-term persistence of the Myxoma virus in European rabbits Oryctolagus cuniculus introduced to Australia (Fenner \& Ratcliffe, 1965). A non-pathogenic strain of rabbit haemorrhagic disease facilitates endemicity of this morbillivirus in the UK (White et al., 2004). Virulent parasites cannot persist in small host populations unless they also have a reservoir host (Brunner et al., 2004); for example, badgers Meles meles are known to be a wildlife reservoir for bovine tuberculosis (Smith et al., 2001). In rabies, caused by a highly virulent lyssavirus, regional persistence is enabled through re-infection from neighbouring distant populations, because juvenile red foxes Vulpes vulpes regularly disperse long distances just after the reproductive season (Jeltsch et al., 1997). Also, seasonal social aggregation could change transmission dynamics (Hosseini, Dhondt \& Dobson, 2004) as well as host population structure, like group sizes or movement (Cross et al., 2005).

Recent reviews about CSF acknowledge that it is time to consider wild boar behaviour, population dynamics, influence of hunting strategies and influence of the landscape structure when developing an effective management strategy (Moennig, 2000; Artois et al., 2002). This requires integrating ecological knowledge on wild boar and epidemiology in pigs, in order to delineate potential factors influencing disease spread and persistence. Different factors have been claimed responsible for the disease expansion and cycling, related to both host population factors and viral characteristics. However, the knowledge about CSF in wild boar populations is only fragmentary. Consequently, we need a critical compilation of current knowledge to discriminate between strengths and weaknesses in understanding of the system and derive credible and defensible management recommendations. This is especially important for countries where wild boar are currently expanding in range and number, e.g. in England and Scandinavia (Goulding et al., 2003).

The aim of this review is to assemble and structure current ecological and epidemiological knowledge of CSF persistence. We define persistence of CSF as being an endemic, recurrent infection within a closed, spatially restricted population. We determine whether general rules can be derived that explain the observed long-term patterns of disease cycling via mechanistic processes and their interaction. We highlight the consequences of the putative factors responsible for disease persistence.

\section{THE HOST-VIRUS SYSTEM}

Understanding CSF persistence in wild boar requires understanding of the complex population ecology of the host, the epidemiology of virus transmission and the effect of human 
management. Most current knowledge of CSF epidemiology comes from investigations in domestic pigs, not in wild boar. We must bear in mind that laboratory experiments are often carried out with higher infectious doses than occur under natural conditions. Yet it is not resolved how, or to what extent, this epidemiological knowledge can be extrapolated to ecological scenarios. Here, we review current ideas on epidemiology, ecology and management, then discuss hypotheses about disease dynamics in wild populations as a framework for different management strategies.

\section{Wild boar population characteristics}

The ecology of the wild boar, a group-living host, has several attributes that are potentially relevant for the spread of the disease. Wild boar social structure, dispersal and population densities are the three primary aspects of the species ecology relevant to the understanding of epidemics, because they relate to the spread of the virus within a group and to spread between groups.

\section{Social organization and seasonal population characteristics}

Female wild boar typically live in social groups sharing exclusive core areas within their home ranges. These reproductive groups consist of related subadult ( $>1$ year) and adult ( $>2$ years) females and their piglets. Groups of up to 30-40 individuals have been reported in nonhunted areas. In hunted populations, group size may be reduced to only 1 or 2 adult females and about 5-10 individuals. This structure exists all year although age-dependent composition of the family group does vary. The groups are spatially restricted to home ranges of about $4-20 \mathrm{~km}^{2}$ (Leaper et al., 1999).

Adult males are frequently solitary, but subadult males often roam together in small groups (Fernandez-Llario, Carranza \& Hidalgo de Trucios, 1996). During the autumn rutting season, males associate with the female groups for mating. Although it has been demonstrated under experimental conditions that semen of infected male pigs can contain CSFV and the virus can be transmitted to sows and their foetuses (de Smit et al., 1999), evidence is missing for the wild boar.

Subadult females split up and disperse with other subadult females of their natal group to constitute a new social group, although sometimes they may return to their native group in autumn, together with their newborn piglets (Dardallion, 1988). Female groups do not seem to associate with other families, although the respective home ranges may overlap. Thus, group splitting by subadult females extends the spatial range of possible contacts but happens only once a year, normally between September and December. Movement distances of subadult females have been recorded up to $20 \mathrm{~km}$, whereas mean distance was $4.5 \mathrm{~km}$ in one study in Sweden. Mean seasonal distances in subadult males were around $17 \mathrm{~km}$, but single individuals were observed to move up to $100 \mathrm{~km}$ (Truvé \& Lemel, 2003). Hence, the virus might be spread over longer distances in suitable habitat by this process, although no proof is available that infected wild boar are still able to disperse long distances.

\section{Host abundance and density in European populations}

Since the early 1950s, wild boar populations have increased both in number and distribution throughout Europe, apparently due to lack of predators, extreme adaptability, artificial feeding and mild winters (Bieber \& Ruf, 2005). France, Germany and Italy host several hundreds of thousands of wild boar, and the present population in European Union member states is estimated between 800000 and 1 million (Saez-Royuela \& Telleria, 1986; Artois et al., 2002). 
Wild boar densities can vary markedly, both spatially and temporally, depending on factors such as habitat composition, hunting management and density of populations after farrowing in spring. Density is strongly linked to the availability of high-energy foods such as mast in many natural areas where management does not include supplementary feeding (Massei, Genov \& Staines, 1996). For example, in the forests of Poland, density is known to vary between 1.5 and 10 individuals per $\mathrm{km}^{2}$ (Andrzejewski \& Jezierski, 1978).

\section{The epidemiology of CSF}

Transmission and course of infection at the individual level

Within social groups, the virus is transmitted by direct and indirect contact, especially between piglets. Between social groups, transmission can be due to contact during the rutting season, male dispersers and establishment of new social groups (Kaden, 1999). Contact with contaminated excretions and carcasses can also contribute to the spread of CSF in the wild boar population, as the virus survives in the environment under certain conditions for several days or even weeks (Edwards, 2000; Ribbens et al., 2004b; but see Dewulf et al., 2002b).

Insects (flies) have been reported as possible vectors for CSF (Dahle \& Liess, 1992), and airborne spread may also occur, as shown in housing experiments (Terpstra, 1987, 1988; Dewulf et al., 2002a). But these factors do not seem to play a significant role.

The incubation period is, on average, 5-10 days (Moennig, 2000). After infection, the clinical courses of CSF range widely from peracute to subclinical to immune outcomes. Several factors have been proposed to influence this variability in pigs, including the age and condition of the infected individual (immune response) and the virus strain's virulence (Tables 1 and 2; Dahle \& Liess, 1992; Moennig, 2000; Paton \& Greiser-Wilke, 2003). The disease normally kills a higher proportion of young wild boar, because their immune system is not fully developed, whereas in the adult cohort, infections are more likely to result in a lower mortality rate and higher level of immunity.

The acute form is characterized in domestic pigs by high fever, leukopaenia, and haemorrhages of skin and inner organs. Animals showing the acute course die within 30 days. If the animal shows disease symptoms and sheds the virus longer than 30 days, the disease course is classified as chronic. These pigs may repeatedly shed the virus. Lifespans of chronically infected pigs of up to 152 days are reported (Depner, Moennig \& Liess, 1997). However, in wild boar only the acute course has so far been described (Mengeling \& Cheville, 1968; Dahle \& Liess, 1992). Survival of the infected animal is due to the development of long-lasting immunity. This course is classified as transient infection because these animals shed the virus for 1-2 weeks before they become immune. Pigs that have recovered may be protected against CSF for their lifetime (Rossi et al., 2005a).

If the mother sow has antibodies, e.g. after surviving an infection, a certain level of maternally derived antibodies (MDA) is detectable in offspring for the first 8-12 weeks (passive immunization). After these 3 months, low levels of MDA have been detected up to 12 months post partum (K. Depner, personal communication). For such 'partially protected piglets' the clinical course of a CSF infection is more often transient than lethal (Depner et al., 2000).

Vertical transmission of CSF leads to prenatal infections, i.e. from the mother to the foetus, which can result in different outcomes depending on the developmental stage of the immune system in a foetus (Artois et al., 2002). Vertical transmission only occurs when at the time of conception the mother sow is antibody negative. Early infections of the pregnant sow normally result in reduced birth probability (abortion, stillbirth), whereas infections close to birth can result in normal and non-infected piglets. But in the middle of the pregnancy period, intrauterine infected piglets are observed (Table 3). Although these animals eventually all die, 
Table 1. Disease courses and their nomenclature in the literature. In former literature reviews (e.g. Dahle \& Liess, 1992), the viraemic and chronic disease course was included under 'chronic' disease course or 'persistent infections' (temporal aspect). Here these are distinguished, since they differ by immune reaction

\begin{tabular}{|c|c|c|c|}
\hline Used & Synonyms & Immune reaction & Description \\
\hline \multicolumn{4}{|c|}{ Post-natal (horizontal transmission) } \\
\hline Transient & & $\begin{array}{l}\text { Immuno-competent individuals; } \\
\text { increase of AB (active immunization); } \\
\text { partially protected piglets by MDA } \\
\text { (passive immunization) }\end{array}$ & $\begin{array}{l}\text { Protective reactor: short-term virus } \\
\text { shedders - latency period - immune }\end{array}$ \\
\hline Acute & Lethal, acute & Immuno-competent individuals & $\begin{array}{l}\text { Heavy reactor: virus shedding for less } \\
\text { than } 30 \text { days - dying }\end{array}$ \\
\hline Chronic & Lethal, chronic, persistently infected & & $\begin{array}{l}\text { Weak reactor: virus shedding } 30 \text { up to } \\
150 \text { days - but eventually dying }\end{array}$ \\
\hline \multicolumn{4}{|c|}{ Prenatal (vertical transmission) } \\
\hline Intrauterine infection & $\begin{array}{l}\text { Viraemic, late-onset CSF, persistently, } \\
\text { prenatally, transplacentally or } \\
\text { congenitally infected }\end{array}$ & Immunotolerant or immuno-incompetent & $\begin{array}{l}\text { Piglets can be protected by MDA the } \\
\text { first weeks of life, but not necessarily. } \\
\text { Virus replicating, no development of } \\
\text { antibodies - eventually dying }\end{array}$ \\
\hline
\end{tabular}

AB, antibodies; CSF, classical swine fever; MDA, maternally derived antibodies. 
Table 2. Overview of clinical studies with experimental infection, showing the high variability of the disease outcome

\begin{tabular}{|c|c|c|c|c|c|c|c|c|c|c|}
\hline \multirow[b]{2}{*}{ Clinical study } & \multirow[b]{2}{*}{ Virus isolate } & \multirow[b]{2}{*}{ Virulence } & \multirow[b]{2}{*}{$N$} & \multirow[b]{2}{*}{ Age class of pigs } & \multirow{2}{*}{$\begin{array}{l}\text { Duration until } \\
\text { death* } \\
\text { or killing } \\
\text { (days) }\end{array}$} & \multicolumn{4}{|c|}{ Disease course $(n, \%)$} & \multirow[b]{2}{*}{ Reference } \\
\hline & & & & & & Acute & Chronic & Transient & Negative & \\
\hline $\begin{array}{l}\text { Challenge and } \\
\text { contact }\end{array}$ & 'Spante’ & Low & 8 & $\begin{array}{l}\text { Weaner pigs and } \\
\text { wild boar } \\
\text { yearlings }\end{array}$ & & - & - & 4 & & Kaden et al. (2000a) \\
\hline Challenge & FIN 3086 & Low & 20 & $15-20 \mathrm{~kg}$ & 130 & 8 & - & 12 & - & $\begin{array}{c}\text { Plateau, Vannier \& } \\
\text { Tillon (1980) }\end{array}$ \\
\hline Contact & & & & $\begin{array}{l}\text { piglets } \\
\text { subadults } \\
\text { adults }\end{array}$ & & & & $\begin{array}{ll}50 \% & 75 \% \\
80 \% & 90 \% \\
90 \% & 97 \%\end{array}$ & $\begin{array}{l}- \\
- \\
-\end{array}$ & $\begin{array}{l}\text { C. Staubach (pers. } \\
\text { com.) }\end{array}$ \\
\hline $\begin{array}{c}\text { Contact and } \\
\text { challenge }\end{array}$ & $\begin{array}{l}\text { Similar to } \\
\text { 'Lorraine 92' } \\
\text { Subgroup } 2.3\end{array}$ & Moderate & $\begin{array}{l}91 \\
23 \\
14\end{array}$ & $\begin{array}{l}\text { Weaner pigs } \\
\text { Fattening sows } \\
\text { Sows }\end{array}$ & $9-75$ & & & $\begin{array}{l}32 \% \\
52 \% \\
86 \%\end{array}$ & $\begin{array}{l}- \\
- \\
-\end{array}$ & $\begin{array}{l}\text { Dewulf et al. (2004) } \\
\quad \text { (review) }\end{array}$ \\
\hline Challenge & CSF277/ Pader & Moderate & 5 & $\begin{array}{l}\text { Wild boar piglets } \\
\text { (partially } \\
\text { protected by } \\
\text { MDA) }\end{array}$ & (all survived) & & & 5 & - & Depner et al. (2000) \\
\hline Contact & Similar to 'Lorraine 92' & Moderate & 29 & Weaner pigs & 60 & - & 12 & 17 & - & $\begin{array}{l}\text { Dewulf et al. } \\
\text { (2001b) }\end{array}$ \\
\hline Challenge & Similar to 'Lorraine 92' & Moderate & 2 & 8 months old & $21 *$ & 2 & & & - & Dewulf et al. (2002c) \\
\hline Challenge & Subgroup 2.2 & Moderate & 4 & $\begin{array}{l}5 \text { weeks old } \\
\text { (partially } \\
\text { protected by } \\
\text { MDA) }\end{array}$ & 12 & & & 4 & - & $\begin{array}{l}\text { Suradhat \& } \\
\text { Damrongwatanapokin } \\
\text { (2003) }\end{array}$ \\
\hline Challenge & 'Manche' & & 5 & 6-16 weeks old & $18^{*}$ & 5 & & & - & Chenut et al. (1999) \\
\hline \multirow[t]{2}{*}{ Challenge } & ALD & High & 10 & $\begin{array}{l}\text { Weaner pigs } \\
(25-30 \mathrm{~kg})\end{array}$ & 30 & 10 & & & - & Narita et al. (2000) \\
\hline & Kanagawa/74 & Low & 5 & & & & 5 & & - & \\
\hline \multirow[t]{3}{*}{ Challenge } & Ames & High & 6 & $7-21 \mathrm{~kg}$ & & 2 & $\begin{array}{l}\text { Rest } \\
\text { killed }\end{array}$ & & & $\begin{array}{l}\text { Mengeling \& Packer } \\
\text { (1969) }\end{array}$ \\
\hline & Vac & Low & 10 & & & & & & & \\
\hline & 331 (85) and 331 & Moderate & 16 & & $70 *$ & & 6 & & & \\
\hline
\end{tabular}


Challenge

$$
\text { vA187-1, cp vA187-1 }
$$

vA187-Ubi, CAP

Moderate

Low

CSF0277 (genotype 2.1)

Moderate

CSF0537 (genotype 2.2)

CSF0634 (genotype 2.3)

CSF0123 (genotype 2.3)

CSF0902 (genotype 1.1)

Challenge

Alfort 187

1829-NVP

(genotype 2.3

Rostock)

Challenge and

11722-WIL

contact

(genotype 2.3

(piglets)

Rostock)

Challenge

331

and contact

Challenge

Diepholz1/Han 94

Visbek/Han 95

Challenge

and contact

Diepholz1/Han 94

Visbek/Han 95

Challenge

Diepholz1/Han 94

Visbek/Han 95

Challenge

and contact

Challenge

'Brescia’, genotype 1.2

Moderate

Moderate

Moderate

Moderate

moderate

Moderate

High

7 weeks old

8-12 weeks

$$
\text { (15-25 kg) }
$$

$49 *$

Mittelholzer et al. (2000)

Floegel-Niesmann et al. (2003)

Kaden et al. (2004)

Subadult wild boar, 31

18 months old

4 Wild boar piglets, 34

8 weeks old

3 Subadult wild boar, 68

8 months old

1 Adult wild boar

69 - $2-4$

Contact

2 Wild boar piglets 20*

$21 *$

40 Weaner pigs

$90 *$

Adult sow

ca. $18 *$

Subadult pigs

(25*

10-day-old piglets ca. 25*

2 7- to 8-week-old

$14 *$

pigs

5

From experiments with vaccination, we only summarized the results of the non-vaccinated control group. Not all columns are filled in the table, as the experiments were not designed for analysing the proportion of acute, chronic or transient infections.

*N: total number of pigs investigated; n: number of pigs suffering from a certain disease course (acute, chronic, transient) of those that got infected; MDA: maternally

derived antibodies. 
Table 3. Overview of studies with pregnant sows and congenital persistently infected offspring

\begin{tabular}{|c|c|c|c|c|c|c|c|c|}
\hline \multirow{3}{*}{$\begin{array}{l}\text { Time of gestation when } \\
\text { sows challenged (days) }\end{array}$} & \multirow[b]{3}{*}{ Virus isolate } & \multirow[b]{3}{*}{ Virulence } & \multirow{3}{*}{$\begin{array}{l}N \text { of } \\
\text { piglets }\end{array}$} & \multirow{3}{*}{$\begin{array}{l}\text { Average survival time of } \\
\text { viraemic piglets (mean, } \\
\text { range) }\end{array}$} & \multicolumn{3}{|c|}{ Offspring $(n)$} & \multirow[b]{3}{*}{ Reference } \\
\hline & & & & & \multicolumn{2}{|l|}{ Alive } & \multirow[b]{2}{*}{ Dead } & \\
\hline & & & & & Viraemic & Normal & & \\
\hline & ‘Bergen’' & Low & 22 & $\begin{array}{l}6 \text { months, } 2-11 \text { months } \\
\quad(n=5)\end{array}$ & 17 & - & 5 & $\begin{array}{l}\text { Van Oirschot (1977); } \\
\text { Van Oirschot \& Terpstra } \\
\text { (1977) }\end{array}$ \\
\hline 65 & 'Glentorf' & Low & 56 & - & 14 & - & 42 & Ahrens et al. (2000) \\
\hline $40-41$ & 'Glentorf' & Low & 37 & 2-8 weeks & 6 & 11 & 20 & Meyer et al. (1981) \\
\hline $68-69$ & & & 41 & & 17 & 1 & 23 & \\
\hline 87-90 & & & 43 & & 16 & 18 & 9 & \\
\hline $65-67$ & Glentorf & Low & 59 & - & $\begin{array}{l}35 \text { viraemi } \\
\text { and aliv }\end{array}$ & $\begin{array}{l}\text { f } 45 \text { (dead } \\
\text { gether) }\end{array}$ & 23 & Frey et al. (1980) \\
\hline 85 & & & 30 & & $\begin{array}{l}4 \text { viraemic } \\
\text { and aliv }\end{array}$ & $\begin{array}{l}27 \text { (dead } \\
\text { gether) }\end{array}$ & 11 & \\
\hline $94-95$ & & & 29 & & 4 & & 0 & \\
\hline $104-111$ & & & 16 & & & & & \\
\hline $31-55$ & $\begin{array}{l}\text { Similar to 'souche } \\
\text { Lorraine'; genotype } 2.3\end{array}$ & Moderate & 113 & - & 74 & & 28 & Dewulf et al. (2001a) \\
\hline $87-92 *$ & $\begin{array}{l}\text { Diepholz1/Han } 94 \text { Visbek/ } \\
\text { Han } 95\end{array}$ & High & 6 & 39 days & 1 & 5 & - & Depner et al. (1995) \\
\hline
\end{tabular}

* Mother sow already had a low level of neutralizing antibodies against bovine viral disease virus (BVDV). Such an infection prior to classical swine fever (CSF) infection usually protects pigs against clinical disease and may obscure the presence of high-virulent CSFV (Dahle et al. 1993 in Depner et al., 1995). 
a persistent infection was observed in experimental studies. The longest infectious period of wild boar piglets was about 40 days (Depner et al., 1995) and up to 11 months for a domestic piglet (Van Oirschot \& Terpstra, 1977). Intrauterine infected wild boar piglets might not survive for an equally long time because living conditions in the field are much harder (Moennig et al., 1999).

Prevalence, incidence and transmission at the population level

In continental Europe, CSF is only prevalent in a limited number of foci. At the beginning of the epidemic, all age classes seem to be affected by increased mortality, but the majority of deaths are of young animals. Peaks in mortality have been observed after initial virus introduction, followed by a slow progressive decrease in the infection rate over a long period of time, which is characterized by increasing sero-conversion in adults; that is, surviving adults are getting immune (Artois et al., 2002). Prevalence is highly variable depending on the time after introduction, e.g. 34\% virus positive after the beginning of an outbreak and 1.5\% one year later, and 5\% sero-positive shortly after the outbreak and 55\% one year later in an outbreak in Italy (Zanardi et al., 2003).

In previous epizootics it has been observed that whole cohorts died out (Kaden, 1999), but in recent years, the infection was seldom observed to be self-limiting (Ferrari et al., 1998; Fritzemeier et al., 1998). Sometimes the virus was circulating for years (Laddomada et al., 1994; Fritzemeier et al., 1998; Kern et al., 1999), showing an oscillating pattern with periodic peaks, but with a decreasing trend (Laddomada, 2000). Ongoing persistence in the field is usually demonstrated by the detection of antibodies in young boar older than 3 months (i.e. no longer having MDA; Artois et al. 2002). In the following section, we discuss the current hypotheses that might explain why endemic situations have increased.

\section{ECOLOGY AND EPIDEMIOLOGY}

Attempts to explain the cycling of CSF have focused on a variety of aspects, differing in their emphasis on characteristics of boar ecology or disease-related processes. For example, on the host side, increased density as well as the large size of the wild boar population is claimed to be responsible for more endemic situations of CSF in recent years, whereas on the epidemiological side, prenatally infected piglets, partially protected piglets or a moderate virulence of the virus are hypothesized to play a crucial role in CSF persistence. Figure 1 shows the complex interplay of ecological and epidemiological factors as well as the influence of management and the environment that we will discuss.

\section{Disease-related processes}

Intrauterine infected piglets

The mechanism of virus spread through prenatally infected piglets is frequently assumed to play a key role in the persistence of CSF. If intrauterine infections result in a prolonged virus-shedding period compared with naïve post-natal infections in piglets (Van Oirschot \& Terpstra, 1977; Liess, 1987; Terpstra, 1988; Kern et al., 1999; Laddomada, 2000), then persistent infection in these piglets might bridge temporal gaps in the infection chain (Kern et al., 1999).

On the other hand, in endemic areas intrauterine infected piglets are unlikely to occur at a substantial rate due to the immunity already acquired by older animals. This suggests that young wild boar persistently infected by transplacental virus transmission do not play a crucial role in the persistence of CSF in wild boar (Moennig et al., 1999; Kaden et al., 2005).

In one study, prenatally infected piglets survived for more than 2 months (see Van Oirschot \& Terpstra, 1977). Another study with a virus strain of similarly low virulence indicated that 


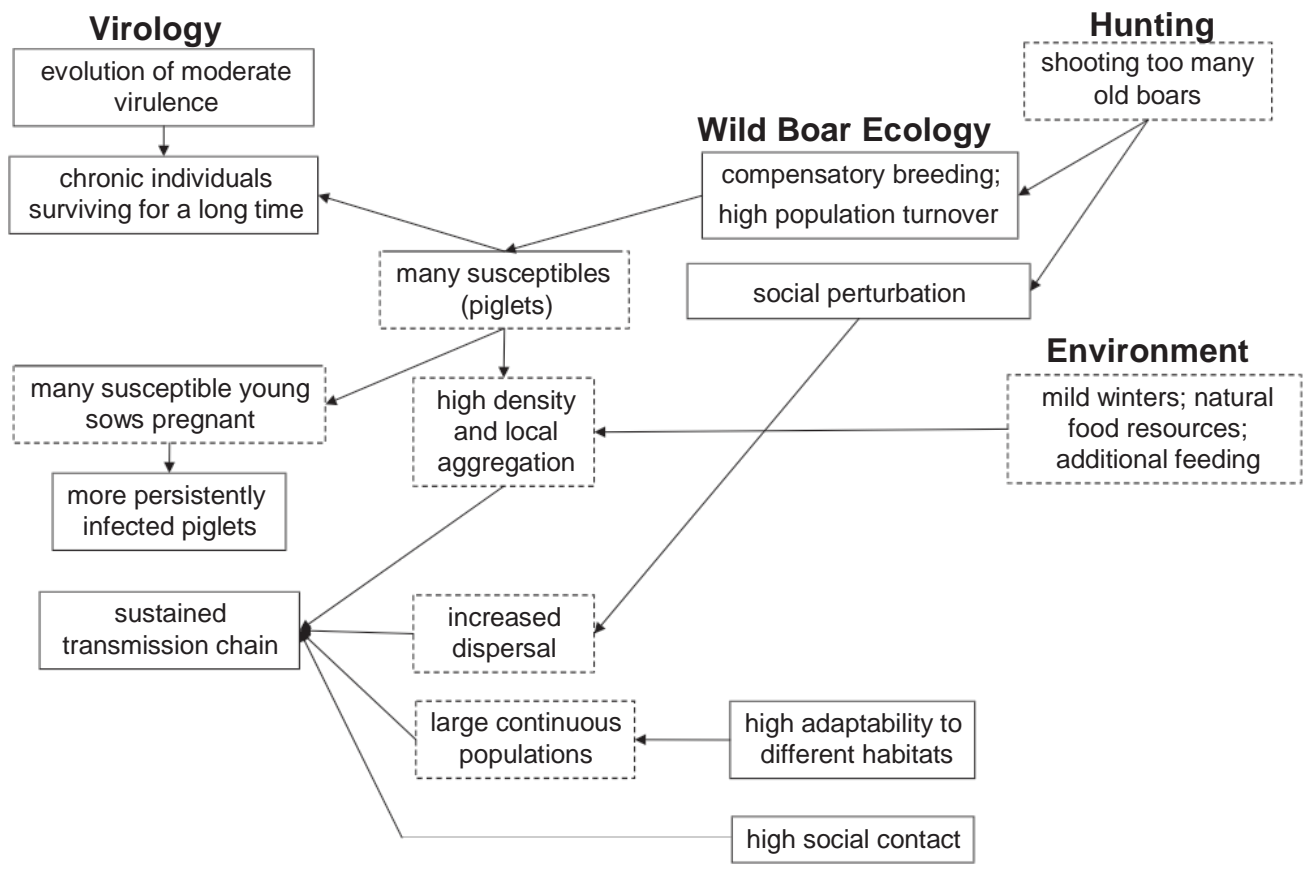

Fig. 1. The interplay of host ecology and epidemiology in the persistence of the disease.

the piglets only survived to a maximum of 8 weeks (Table 3; Meyer et al., 1981). Although we concur with the potential importance of long-lasting infections as drivers for CSF persistence in wild populations, we doubt that intrauterine infected piglets will play that part, unless they survive and continue to be infectious for much longer than identified in previous studies. When asking for persistence, we consider the endemic situation in contrast to an epidemic, where the occurrence of successful prenatal infections is reduced by the immunity of older animals. As the risk of having persistently infected piglets mostly relates to social groups with primary infections, i.e. fully susceptible groups, we suggest that this hypothesis can be rejected as the main driver for CSF persistence under natural conditions.

\section{Transient infections in partially protected piglets}

The infection of piglets partially protected up to 1 year by MDA may play a crucial role in the spread of CSF. These pigs may contribute to the maintenance of long-lasting epizootics, because they are not severely affected by the disease and can still move (and carry the virus) long distances (Depner et al., 2000). During group splitting and dispersal, such animals would be a plausible force for spatial viral spread. However, infections of partially protected piglets are shown to be rather transient, i.e. running for at most 3 weeks post infection (Depner et al., 2000). Thus, all infected partially protected piglets will have recovered before they reach the age to disperse. We conclude that the hypothesis per se is not suited to explaining disease persistence in wild boar populations.

\section{Differences in virulence}

Sustained transmission is least likely for virulent parasites, i.e. with high transmission rates and short infectious periods. They cannot persist in small host populations unless they also 
have a reservoir host (Brunner et al., 2004). Although some species like the European rabbit may eventually be infected by CSFV (Chenut et al., 1999), other animals are not reservoirs and even their role as CSFV vectors remains doubtful (Dewulf et al., 2001c; Kaden et al., 2003; Ribbens et al., 2004a). The Virulence Evolution Hypothesis claims that strains of intermediate virulence are the outcome of natural selection to balance between the virus' need to reproduce and the costs of harming the host (Gandon, van Baalen \& Jansen, 2002; Mackinnon \& Read, 2004).

According to descriptions from the mid-20th century, CSF used to be an acute disease with short incubation period and high mortality rates. The course of the disease has since changed dramatically. Today, the peracute form has disappeared and the acute form no longer results in high mortality rates. In addition, the chronic form of the disease is more common in pigs. The different clinical pictures can be attributed to CSFV strains of varying virulence (Meyers \& Thiel, 1996). This striking inter-animal variability in disease outcome of chronic and acute infections in moderately virulent strains might facilitate epidemic as well as endemic situations (Mittelholzer et al., 2000; Uttenthal et al., 2003).

The hypothesis is underpinned by recent genotyping analyses showing a switch from virulent group 1 viruses prior to the 1970s to group 2 viruses (Paton et al., 2000). Moderately virulent viruses of subgroup 2.2 and 2.3 were present in wild boar populations of France, Austria, Italy and Germany, partly in endemic areas (Fritzemeier et al., 1998; Greiser-Wilke et al., 2000; Biagetti et al. 2001; Kaden et al., 2004). In Tuscany, Italy, a decrease in CSFV virulence during an epidemic in wild boar has been described (Ferrari et al., 1998). However, Depner et al. (1997) concluded that the changing clinical picture of CSF observed during the recent epizootic in domestic pigs in Lower Saxony, Germany, was mainly related to host factors such as age and genetic characteristics of the pig, rather than to the virulence of the virus, because even with a highly virulent virus strain, there was a high variability in disease outcome. Whether disease outcome is related to the virulence of the virus or to the condition of the animals is still discussed (Floegel-Niesmann et al., 2003). Genetic resistance, for example, to bovine tuberculosis is suggested in Iberian wild boar (Acevedo-Whitehouse et al., 2005), and although it is not yet recorded, genetic resistance to CSF may also be possible.

The most plausible explanation for virus perpetuation seems to be the change from a highly virulent virus strain to a strain of moderate virulence. What is relevant in terms of population epidemiology is that a higher number of transients and chronics in the population (because of either lower virus lethality or higher host resistance) can be responsible for the persistence of the disease. For simplifying reasons, and because it is still under discussion whether it is due to host or viral traits, we refer to the virulence of the virus in the course of this review as a highly variable disease outcome.

The mechanism behind virus circulation of moderately virulent strains would be that more infections will be transient, guaranteeing sustained reproduction of susceptible individuals due to surviving adults and, in addition, more chronic infections. The latter can shed the virus for up to 6 months in pigs. Thus, chronically infected individuals will occur independent of the state of the epidemic (i.e. the immunity level in the population). However, so far only the acute form has been described in the wild boar (Dahle \& Liess, 1992), presumably because identifying chronic disease in the field is not possible at the moment.

Low virulence also increases the probability of having intrauterine infected piglets, as more sows get transient infections. Most studies were conducted with a low virulence virus (Table 3): if low virulence viruses result in more chronic infections with long lifespans in infectious individuals, the detected long life times of prenatally infected piglets can also simply be due to mothers infected with a less-virulent strain. 


\section{Host-related processes}

Population characteristics and dispersal

The social structure of wild boar populations may favour the spread of diseases. Only brief contact is required, and that level of contact is very high within social groups or when aggregating around artificial feeding or watering sites (e.g. Vicente et al., 2004, 2005). After a population crash, a typical aspect of wild boar populations under natural conditions (Okarma et al., 1995; Jedrzejewska et al., 1997; Massei et al., 1997), is a high population production, which contributes to the rapid establishment of a newly susceptible generation. Also, wild boar show intense responses to food pulses (mast years, artificial feeding) with increased reproduction (Bieber \& Ruf, 2005). As newborns are numerous and also the most vulnerable age class for CSF, these cycles might mediate the continued spread in local areas (Laddomada, 2000). Further, seasonal dispersal may enhance spread between regions. During the dispersal season, previously infected social groups with a number of susceptible offspring can come into contact with infected animals. Thus, dispersal may link the 'susceptible patches' even within the same population (Laddomada, 2000). Therefore, virus persistence in wild boar populations could be a result of a fast re-establishment of a new susceptible population as well as immigration.

\section{Population size (spatial extent) and density}

The increase in wild boar populations has been linked to virus perpetuation. It seems striking that the cases of endemic situations in recent years coincide with the population explosion of wild boar at the beginning of the 1950 (Jedrzejewska et al., 1997). Increase in wild boar numbers is not only related to an increase in wild boar densities, but also to an extended spatial range. Here, we refer to population size as the spatial extent a connected population covers and to density as the number of individuals living in a certain area, and review the effects of size and density separately.

(a) Population size. In general, theory predicts that a large population contributes to long-lasting epizootics, as it takes a longer time until the whole population has been completely exposed to infection (Mollison \& Levin, 1995; Hudson et al., 2002). If the landscape is large or the disease spreads very slowly, a fully susceptible new generation can be raised 'behind the primary epidemic wave'. Thus, a second infection wave can occur, although with lower peaks of infection, because many adult individuals are already immune (Swinton et al., 2002). This corresponds with the oscillating pattern found during an epidemic in France, with peaks of disease occurring every 2 years, but with a trend towards a decreased size of the peaks (Laddomada, 2000).

However, we think that this hypothesis does not work well with a highly virulent CSF virus for locally restricted areas. Therein, the depletion of whole groups (Kaden, 1999) makes reproduction and thus secondary infections in the population unlikely, and the infection might become self-limiting after the primary outbreak. However, the virus has been demonstrated to circulate in small foci (Laddomada et al., 1994), indicating that the population size hypothesis is not sufficient to explain CSF persistence.

(b) Population density. Variability in population density is one of the prime factors for explaining differences in disease persistence in epidemics and particularly for CSF virus cycling, assuming that a high wild boar density can contribute to keep the CSF virus transmission chain connected (Kern et al., 1999; Rossi et al., 2005a,b). For many infectious diseases, transmission is assumed to be a density-dependent process. Below a critical host population density, the contact rate between infected and susceptible hosts is too low to ensure transmission, and so the pathogen goes extinct (Brunner et al., 2004). Thus, epide- 
miological studies often refer to a threshold density below which the disease is likely to fade out. For CSF, the density threshold was calculated with deterministic and stochastic models, and for different populations, to be about 1 individual per $\mathrm{km}^{2}$ (range 0.6-1.1) (Guberti et al., 1998) or 6 individuals per $\mathrm{km}^{2}$ (range 5-10) (Hone, Pech \& Yip, 1992). Nevertheless, CSF has persisted for many years in low-density populations as well as in high-density populations (Artois et al., 2002). This has also been found for rabies in foxes, and recent modelling efforts for territorial wildlife species have found evidence that density alone does not determine disease fade-out (Sterner \& Smith, 2006). This may be due to the fact that the density concept is related to a crowding of individuals per area, which does not directly alter the temporal dynamics of the epidemic, i.e. the bridging of the 'troughs' (Lloyd-Smith et al., 2005) between epidemic peaks via the replenishment of the susceptible pool through reproduction.

However, local differences in spatial and temporal aggregation may explain CSF virus transmission and perpetuation, as has been linked with a number of other infectious diseases in wild boar, e.g. Circovirus (Vicente et al., 2004) or Aujetzky's disease (Vicente et al., 2005). These spatio-temporal aggregations may be due to habitat fragmentation but most obviously to artificial feeding and, in southern Europe, watering (Gortázar et al., 2006). Artificial feeding or watering also has a positive feedback on population growth and thus again on density. There is another side effect of artificial feeding: when wild boar are in good condition due to high food availability, it is more probable that chronic or transient infections will occur, because the disease outcome is also related to the host condition.

In summary, large host population numbers, either occupying large connected areas or living at high local densities, increase the likelihood of disease persistence simply because more rare events happen (like chronic disease courses, long-distance dispersal) and more immune animals can reproduce. Thus, with persistence being determined by relationships between host numbers and the timescales of demography and transmission, there is a gradual dependence on host numbers (Lloyd-Smith et al., 2005). Therefore, a large host number might support the persistence mechanism of CSF, but is rather not the key concept allowing discrimination between persistence and fade-out.

\section{CURRENT MANAGEMENT}

Both increases in wild boar populations and CSF virus evolution towards moderate virulence have occurred in parallel, and none of the most plausible hypotheses about higher persistence in recent times can be rejected. Both hypotheses have implications for the management of the disease. If large wild boar numbers due to increased density or available habitat were to blame for persistence alone, reducing population density could be the appropriate management scheme; on the other hand, vaccination may be more successful if a moderately virulent virus was to blame.

\section{Hunting}

Bieber \& Ruf (2005) present a hunting scheme for wild boar adjusted to changing environmental conditions. In growing populations under good environmental conditions as can be assumed for most Central European wild boar populations, yearly survival of juveniles $<8$ months of age should be reduced to about $15 \%$ to limit the population growth rate to $\mathbf{I S} 1$. This analysis has also shown that preferential hunting of adult females in favourable habitats would be ineffective, because even if the survival of adults was below $10 \%$, population growth would not drop to $\mathrm{l}=1$ due to increased reproductive success (larger litter sizes). In Germany for example, it has been shown that the hunting bag is far from a juvenile reduction of $85 \%$, with only up to $50 \%$ young wild boar less than 1 year shot, but with the 
hunting effort already being at its upper limit (Depner, Kern \& Liess, 1998). Shooting a high percentage of adults keeps the wild boar population at a very young stage, increasing the number of susceptible animals and providing ideal conditions for the further spread of CSF. Additionally, older wild boar that are immune or less susceptible to infection are removed.

Another factor also comes into play: wild boar group structure is normally stable, but is subject to considerable disruption during the hunting season, where this exists. These groups are normally guided by adult sows, but if all the social group's adult or subadult females have disappeared, the youngsters may move up to $50 \mathrm{~km}$ together (Genov \& Ferrari, 1998; Moennig et al., 1999). In this way, the virus could be spread over longer distances. Hunting can cause home ranges to increase up to four times the normal size (Boitani et al., 1994; Maillard \& Fournier, 1995; but see Sodeikat \& Pohlmeyer, 2002). Similarly, due to the interaction between culling and population and disease dynamics, badger culling appears to have failed to control bovine tuberculosis in cattle (Woodroffe et al., 2006) or killing of foxes to combat rabies (Smith \& Harris, 1989; Aubert, 1994). These side effects of hunting present challenges for policy development and suggest that areas affected by CSFV need different management schemes than adjacent, non-infected areas, if culling is the method of choice.

\section{Vaccination}

Oral immunization has been introduced as an additional tool to improve group immunity (Kaden et al., 2000b). Based on the CSFV strain 'C', vaccine-laced baits are used in Europe. In clinical studies, this vaccine has been shown to be very effective, making animals immune 1-2 weeks after ingestion of baits (Kaden \& Lange, 2001).

However, field trials in Germany have shown that the immunization of young wild boar was not sufficient in most campaigns (Kaden et al., 2002). This was attributed to the low bait uptake $(<50 \%)$ by young individuals, who are the last in the hierarchy of the group, although average bait removal was about $92 \%$ and bait uptake was demonstrated in about $68 \%$ of shot wild boar (Kaden et al., 2000b). Both hunting and vaccination were obviously not able to reach the youngest animals effectively.

The correct timing of the vaccination campaign is also important. MDA are present up to 3 months in piglets; thus an active immunization of young piglets may only be effective after about the third month of their life (Kaden \& Lange, 2004). As most of the piglets are born in March and April, it can be concluded that the best timing for vaccination campaigns should then be earliest in summer and latest in winter, i.e. 3 months before the reproductive peak to immunize mother sows. Vaccination procedures in Germany consist now of three double vaccinations in spring, summer and autumn, and have been shown stop the epidemic quickly (Kaden et al., 2002).

\section{SYNTHESIS}

When considered in isolation, most hypotheses, e.g. intrauterine infected piglets, seem secondary as drivers for disease persistence; we can gain a consistent conceptual model when putting together all the pieces of knowledge: basically, the involvement of CSFV strains of moderate virulence results in a higher probability of individual chronic disease as well as transient infections, with the surviving individuals producing susceptible offspring. Additionally, high wild boar numbers increase support for the conceptual model: a large connected population area prolongs the time left for an epidemic wave to run through the population, and high local density increases the chance to have individual, chronically infected animals. We suggest that moderate virulence is the primary driver of the disease, catalysed by high wild boar numbers. 
Our review also reveals gaps in current knowledge. It is still not known how disease transmission rates change with host density. This should be investigated in experimental field trials. Another gap is the unknown distribution of mortality rates for different virus strains in wild boar. Furthermore, the spatial structure of the host population is unclear, i.e. whether the wild boar population forms a kind of structured population or whether we have a continuous population with respect to virus transmission; this could be investigated by using spatially explicit epidemiological models.

According to our conceptual model, we can identify the disease management implications, depending on the phase of the epidemic. In an outbreak zone, i.e. an area currently affected by the primary infectious wave and associated with the highest incidence in all age classes, the condition of the hosts should be further reduced to avoid chronic outcomes, e.g. by stopping all artificial feeding. This also limits the contacts between members of different social groups. Hunting to reduce the population size further may be useful, but considering its side effects, it should only be carried out if it can be guaranteed that no infected boar escape the outbreak zone. Vaccination seems useless in the outbreak zone, as it takes 2 weeks to build up immunity. Meanwhile, most of the animals would be infected or shot. In contrast, in the endemic zone, vaccination should be scheduled until the disease is eradicated; in addition, supplementary feeding should be banned. In the risk zone, i.e. the area in the proximity of an outbreak or endemic zone, we also suggest reduced hunting to avoid movements into zones affected by CSFV. Here, intensive emergency vaccination would be useful to increase adult immunity, to lower the probability of having persistently infected offspring, and to protect susceptible newborns via MDA, even if this is only limited in time. Preventively, a well-planned hunting scheme in wild boar populations that are free of CSFV, or in areas neighbouring outbreak or endemic zones, should be carried out. Oral immunization of wild boar can also be a valuable tool, although its economic costs and probability of success should be considered.

In general, surveillance and long-term monitoring of both wild boar populations and CSFV prevalence is of special importance in order that spatial and temporal trends in incidence can be analysed and the likely disease course in wild boar populations predicted (Rossi et al., 2005a). There is also a need for spatially explicit models that reflect important temporal and spatial variation in host and parasite factors to make them useful for managers. In such models, real landscapes where an outbreak has occurred can be implemented to reconstruct the disease course and to test hypotheses and management measures. Such models are still underused (Morgan et al., 2004), although they are perfectly suited to evaluate conceptual models against field data in more detail (McCallum, Barlow \& Hone, 2001).

\section{ACKNOWLEDGEMENTS}

We thank Jürgen Teuffert, Klaus Depner, Christoph Staubach and Volker Kaden for fruitful discussions, and Jane Uhd Jepsen for critical comments on an earlier draft of the manuscript. A special note of thanks goes to Graham C. Smith for editorial advice and anonymous referees for many useful comments. N.F. was supported by a Marie Curie Host Fellowship provided by the European Commission (HPMD-CT-2001-00109).

\section{REFERENCES}

Acevedo-Whitehouse, K., Vicente, J., Gortazar, C., Höfle, U., Fernández-de-Mera, I.G. \& Amos, W. (2005) Genetic resistance to bovine tuberculosis in the Iberian wild boar. Molecular Ecology, 14, 3209-3217. Ahrens, U., Kaden, V., Drexler, C. \& Visser, N. (2000) Efficacy of the classical swine fever (CSF) marker vaccine Porcilis ${ }^{\circledR}$ Pesti in pregnant sows. Veterinary Microbiology, 77, 83-97. 
Andrzejewski, R. \& Jezierski, W. (1978) Management of a wild boar population and its effects on commercial land. Acta Theriologica, 23, 309-339.

Artois, M., Depner, K.R., Guberti, V., Hars, J., Rossi, S. \& Rutili, D. (2002) Classical swine fever (hog cholera) in wild boar in Europe. Revue Scientifique et Technique de l'Office International des Epizooties, 21, 287-303.

Aubert, M. (1994) Control of rabies in foxes: what are the appropriate measures? Veterinary Record, 134, 55-59.

Biagetti, M., Greiser-Wilke, I. \& Rutili, D. (2001) Molecular epidemiology of classical swine fever in Italy. Veterinary Microbiology, 83, 205-215.

Bieber, C. \& Ruf, T. (2005) Population dynamics in wild boar Sus scrofa: ecology, elasticity of growth rate and implications for the management of pulsed resource consumers. Journal of Applied Ecology, 42, 1203-1213.

Boitani, L., Mattei, L., Nonis, D. \& Corsi, F. (1994) Spatial and activity patterns of wild boars in Tuscany, Italy. Journal of Mammalogy, 75, 600-612.

Brunner, J.L., Schock, D.M., Davidson, E.W. \& Collins, J.P. (2004) Intraspecific reservoirs: complex life history and the persistence of a lethal ranavirus. Ecology, 85, 560-566.

Chenut, G., Saintilan, A.F., Burger, C., Rosenthal, F., Cruciere, C., Picard, M., Bruyere, V. \& Albina, E. (1999) Oral immunisation of swine with a classical swine fever vaccine (Chinese strain) and transmission studies in rabbits and sheep. Veterinary Microbiology, 64, 265-276.

Courchamp, F., Pontier, D., Langlais, M. \& Artois, M. (1995) Population dynamics of feline immunodeficiency virus within populations of cats. Journal of Theoretical Biology, 175, 553-560.

Cross, P.C., Lloyd-Smith, J.O., Johnson, P.L.F. \& Getz, W.M. (2005) Duelling timescales of host movement and disease recovery determine invasion of disease in structured populations. Ecology Letters, 8, 587-595.

Dahle, J. \& Liess, B. (1992) A review on classical swine fever infections in pigs: epizootiology, clinical disease, and pathology. Comparative Immunology, Microbiology and Infectious Diseases, 15, 203-211.

Dahle, J., Patzelt, Th., Schagemann, G. \& Liess, B. (1993) Antibody prevalence of hog cholera, bovine viral diarrhoea and Aujeszky's disease virus in wild boars in Northern Germany. Deutsche tierärztliche Wochenschrift, 100, 330-333.

Dardallion, M. (1988) Wild boar social groupings and their seasonal changes in the Camargue, southern France. Zeitschrift für Säugetierkunde, 53, 22-30.

Depner, K.R., Müller, A., Gruber, A., Rodriguez, A., Bickhardt, K. \& Liess, B. (1995) Classical swine fever in wild boar (Sus scrofa). Experimental infections and viral persistence. Deutsche Tierarztliche Wochenschrift, 102, 381-384.

Depner, K.R., Moennig, V. \& Liess, B. (1996) Epidemiologische Betrachtungen zur ‘typischen' und 'atypischen’ Schweinepest. Amtstierärztlicher Dienst und Lebensmittelkontrolle, 3, 335-342.

Depner, K.R., Moennig, V. \& Liess, B. (1997) Epidemiological aspects of the infectious biology of classical swine fever. Praktischer Tierarzt, 78, 63-67.

Depner, K.R., Hinrichs, U., Bickhardt, K., Greiser-Wilke, I., Pohlenz, J., Moennig, V. \& Liess, B. (1997) Influence of breed-related factors on the course of classical swine fever virus infection. Veterinary Record, 140, 506-507.

Depner, K.R., Kern, B. \& Liess, B. (1998) Epidemiologische Relevanz der Persistenz von KSP-Virus beim Schwarzwild (Sus scrofa sp.). Amtstierärztlicher Dienst und Lebensmittelkontrolle, 5, 244-248.

Depner, K.R., Müller, T., Lange, E., Staubach, C. \& Teuffert, J. (2000) Transient classical swine fever virus infection in wild boar piglets partially protected by maternal antibodies. Deutsche Tierarztliche Wochenschrift, 107, 66-68.

Dewulf, J., Laevens, H., Koenen, F., Mintiens, K. \& de Kruif, A. (2001a) An experimental infection with classical swine fever virus in pregnant sows: transmission of the virus, course of the disease, antibody response, and effect on gestation. Journal of Veterinary Medicine B, 48, 591.

Dewulf, J., Laevens, H., Koenen, F., Vanderhallen, H., Mintiens, K., Deluyker, H. \& de Kruif, A. (2001b) An experimental infection with classical swine fever in E2 sub-unit marker vaccine in vaccinated and in non-vaccinated pigs. Vaccine, 19, 475-482.

Dewulf, J., Laevens, H., Koenen, F., Mintiens, K. \& de Kruif, A. (2001c) Evaluation of the potential of dogs, cats and rats to spread classical swine fever virus. Veterinary Record, 149, 212-213.

Dewulf, J., Laevens, H., Koenen, F., Mintiens, K. \& de Kruif, A. (2002a) Airborne transmission of classical swine fever virus under experimental conditions. Veterinary Record, 147, 735-738.

Dewulf, J., Laevens, H., Koenen, F., Mintiens, K. \& de Kruif, A. (2002b) An experimental infection to investigate the indirect transmission of classical swine fever virus by excretions of infected pigs. Journal of Veterinary Medicine B, 49, 452-456.

Dewulf, J., Laevens, H., Koenen, F., Mintiens, K. \& de Kruif, A. (2002c) An E2 sub-unit marker vaccine does not prevent horizontal of vertical transmission of classical swine fever virus. Vaccine, 20, 86-91. 
Dewulf, J., Koenen, F., Mintiens, K., Denis, P., Ribbens, S. \& de Kruif, A. (2004) Analytical performance of several classical swine fever laboratory diagnostic techniques on live animals for detection of infection. Journal of Virological Methods, 119, 137-143.

Edwards, S. (2000) Survival and inactivation of classical swine fever virus. Veterinary Microbiology, 73, 175-181.

Fenner, F. \& Ratcliffe, F.N. (1965) Myxomatosis. Cambridge University Press, Cambridge, UK.

Fernandez-Llario, P., Carranza, J. \& Hidalgo de Trucios, S.J. (1996) Social organization of the wild boar (Sus scrofa) in Donana National Park. Miscellania Zoologica, 19, 9-18.

Ferrari, G., Guidoni, M., Amaddeo, D., Autorino, G.L. \& Forletta, R. (1998) Epidemiology of CSF in wild boar in Toscana. In: Report on Measures to Control Classical Swine Fever in European Wild Boar, pp. 62-66. Commission of the European Communities, Brussels.

Floegel-Niesmann, G., Bunzenthal, C., Fischer, S. \& Moennig, V. (2003) Virulence of recent and former classical swine fever isolates evaluated by their clinical and pathological signs. Journal of Veterinary Medicine B, 50, 214-220.

Frey, H.-R., Liess, B., Richter-Reichhelm, H.B., von Benten, K. \& Trautwein, G. (1980) Experimental transplacental transmission of hog cholera virus in pigs. I. Virological and serological studies. Zentralblad fur Veterinarmedicine B, 27, 154-164.

Fritzemeier, J., Greiser-Wilke, I., Depner, K. \& Moennig, V. (1998) Characterization of CSF virus isolates originating from German wild boar. In: Report on Measures to Control Classical Swine Fever in European Wild Boar, pp. 107-109. Commission of the European Communities, Brussels.

Fritzemeier, J., Teuffert, J., Greiser-Wilke, I., Staubach, C., Schluter, H. \& Moennig, V. (2000) Epidemiology of classical swine fever in Germany in the 1990s. Veterinary Microbiology, 77, 29-41.

Gandon, S., van Baalen, M. \& Jansen, V.A.A. (2002) The evolution of parasite virulence, superinfection, and host resistance. American Naturalist, 159, 658-669.

Genov, P. \& Ferrari, G. (1998) Effect of hunting on the use of space and habitat of wild boars. In: Report on Measures to Control Classical Swine Fever in European Wild Boar, pp. 32-36. Commission of the European Community, Brussels.

Gortázar, C., Acevada, P., Ruiz-Fons, F. \& Vicente, J. (2006) Disease risks and overabundance of game species. European Journal of Wildlife Research, 52(2), 81-87.

Goulding, M.J., Roper, T.J., Smith, G.C. \& Baker, S.J. (2003) Presence of free-living wild boar Sus scrofa in southern England. Wildlife Biology, 9, 15-20.

Greiser-Wilke, I., Fritzemeier, J., Koenen, F., Vanderhallen, H., Rutili, D., De Mia, G.-M., Romero, L., Rosell, R., Sanchez-Vizcaino, J.M. \& San Gabriel, A. (2000) Molecular epidemiology of a large classical swine fever epidemic in the European Union in 1997-1998. Veterinary Microbiology, 77, 17-27.

Guberti, V., Rutili, D., Ferrari, G., Patta, C. \& Oggaino, A. (1998) Estimate the threshold abundance for the persistence of the classical swine fever in the wild boar population of the eastern Sardinia. In: Report on Measures to Control Classical Swine Fever in European Wild Boar, pp. 54-61. Commission of the European Community, Brussels.

Hone, J., Pech, R. \& Yip, P. (1992) Estimation of the dynamics and rate of transmission of classical swine fever (hog cholera) in wild pigs. Epidemiology and Infection, 108, 377-386.

Hosseini, P.R., Dhondt, A.A. \& Dobson, A. (2004) Seasonality and wildlife disease: how seasonal birth, aggregation and variation in immunity affect the dynamics of Mycoplasma gallisepticum in house finches. Proceedings of the Royal Society of London Series B - Biological Sciences, 271, 2569-2577.

Hudson, P.J., Rizzoli, A., Grenfell, B.T., Heesterbeek, H. \& Dobson, A.P. (2002) The Ecology of Wildlife Diseases. Oxford University Press, New York.

Jedrzejewska, B., Jedrzejewski, W., Bunevich, A.N., Milkowski, L. \& Krasinski, Z. (1997) Factors shaping population densities and increase rates on ungulates in Bialowieza Primeval Forest (Poland and Belarus) in the 19th and 20th century. Acta Theriologica, 42, 399-451.

Jeltsch, F., Müller, M.S., Grimm, V., Wissel, C. \& Brandl, R. (1997) Pattern formation triggered by rare events: lessons from the spread of rabies. Proceedings of the Royal Society of London B, 264, 495-503.

Kaden, V. (1999) Control of classical swine fever in wild boar population. Zeitschrift für Jagdwissenschaft, 45 , 45-59.

Kaden, V. \& Lange, B. (2001) Oral immunisation against classical swine fever (CSF): onset and duration of immunity. Veterinary Microbiology, 82, 301-310.

Kaden, V. \& Lange, E. (2004) Development of maternal antibodies after oral vaccination of young female wild boar against classical swine fever. Veterinary Microbiology, 103, 115-119.

Kaden, V., Ziegler, U., Lange, E. \& Dedek, J. (2000a) Classical swine fever virus: clinical, virological, serological and hematological findings after infection of domestic pigs and wild boars with the field isolate 'Spante' originating from wild boar. Berliner und Munchener Tierarztliche Wochenschrift, 113, 412-416. 
Kaden, V., Lange, E., Fischer, U. \& Strebelow, G. (2000b) Oral immunisation of wild boar against classical swine fever: evaluation of the first field study in Germany. Veterinary Microbiology, 73, 239-252.

Kaden, V., Heyne, H., Kiupel, H., Letz, W., Kern, B., Lemmer, U., Gossger, K., Rothe, A., Bohme, H. \& Tyrpe, P. (2002) Oral immunisation of wild boar against classical swine fever: concluding analysis of the recent field trials in Germany. Berliner und Munchener Tierarztliche Wochenschrift, 115, 179185.

Kaden, V., Lange, E., Steyer, H., Bruer, W. \& Langner, Ch (2003) Role of birds in transmission of classical swine fever virus. Journal of Veterinary Medicine B, 50, 357-359.

Kaden, V., Lange, E., Polster, U., Klopfleisch, R. \& Teifke, J.P. (2004) Studies on the virulence of two field isolates of the classical swine fever genotype 2.3 Rostock in wild boars of different age groups. Journal of Veterinary Medicine B, 51, 202-208.

Kaden, V., Steyer, H., Schnabel, J. \& Bruer, W. (2005) Classical swine fever (CSF) in wild boar: the role of the transplacental infection in the perpetuation of CSF. Journal of Veterinary Medicine B, 52, 161.

Kern, B., Depner, K.R., Letz, W., Rott, M., Thalheim, S., Nitschke, B., Plagemann, R. \& Liess, B. (1999) Incidence of classical swine fever (CSF) in wild boar in a densely populated area indicating CSF virus persistence as a mechanism for virus perpetuation. Journal of Veterinary Medicine Series B - Infectious Diseases and Veterinary Public Health, 46, 63-67.

Laddomada, A. (2000) Incidence and control of CSF in wild boar in Europe. Veterinary Microbiology, 73, 121-130.

Laddomada, A., Patta, C., Oggiano, A., Caccia, A., Ruiu, A., Cossu, P. \& Firinu, A. (1994) Epidemiology of classical swine fever in Sardinia: a serological survey of wild boar and comparison with African swine fever. Veterinary Microbiology, 134, 183-187.

Leaper, R., Massei, G., Gorman, M.L. \& Aspinall, R. (1999) The feasibility of reintroducing wild boar (Sus scrofa) to Scotland. Mammal Review, 29, 239-259.

Lenghaus, C., Westbury, H., Collins, B., Ratnamoban, N. \& Morrissy, C. (1994) Overview of the RHD project in Australia. In: Rabbit Haemorrhagic Disease: Issues in Assessment for Biological Control (Ed. by E.R.W.R. Munro), pp. 104-129. Bureau of Resource Sciences, Canberra, Australia.

Liess, B. (1987) Pathogenesis and epidemiology of hog cholera. Annales de recherches veterinaires, 18, 139-145.

Lloyd-Smith, J.O., Cross, P.C., Briggs, C.J., Daugherty, M., Getz, W.M., Latto, J., Sanchze, M.S., Smith, A.B. \& Swei, A. (2005) Should we expect population thresholds for wildlife disease? Trends in Ecology and Evolution, 20, 511-519.

McCallum, H., Barlow, N. \& Hone, J. (2001) How should pathogen transmission be modelled? Trends in Ecology and Evolution, 16, 295-300.

Mackinnon, M.J. \& Read, A.F. (2004) Virulence in malaria: an evolutionary viewpoint. Philosophical Transactions of the Royal Society London B, 359, 965-986.

Maillard, D. \& Fournier, P. (1995) Effects of shooting with hounds on size of resting range of wild boar (Sus scrofa L.) groups in Mediterranean habitat. Ibex, 3, 102-107.

Massei, G., Genov, P.V. \& Staines, B.W. (1996) Diet, food availability, and reproduction of wild boar in a Mediterranean coastal area. Acta Theriologica, 41, 307-320.

Massei, G., Genov, P.V., Staines, B.W. \& Gorman, M.L. (1997) Mortality of wild boar in a Mediterranean area in relation to sex and age. Journal of Zoology (London), 242, 394-400.

Mengeling, W.L. \& Cheville, N.F. (1968) Host response to persistent infection with hog cholera virus. Proceedings of the 72nd Annual Meeting of the United States Animal Health Association (USAHA), 283-296.

Mengeling, W.L. \& Packer, R.A. (1969) Pathogenesis of chronic hog cholera: host response. American Journal of Veterinary Research, 30, 409-417.

Meuwissen, M.P.M., Horst, H.S., Huirne, R.B.M. \& Dijkhuizen, A.A. (1999) A model to estimate the financial consequences of classical swine fever outbreaks: principles and outcomes. Preventive Veterinary Medicine, 42, 249-270.

Meyer, H., Liess, B., Frey, H.-R., Hermanns, W. \& Trautwein, G. (1981) Experimental transplacental transmission of hog cholera virus in pigs. IV. Virological and serological studies in newborn piglets. Zentralblad fur Veterinarmedicine B, 28, 659-668.

Meyers, G. \& Thiel, H.-J. (1996) Molecular characterization of pestiviruses. Advances in Virus Research, 47, 53-118.

Mittelholzer, C., Moser, C., Tratschin, J.-D. \& Hofmann, M.A. (2000) Analysis of classical swine fever virus replication kinetics allows differentitation of highly virulent from avirulent strains. Veterinary Microbiology, 74, 293-308.

Moennig, V. (2000) Introduction to classical swine fever: virus, disease and control policy. Veterinary Microbiology, 73, 93-102. 
Moennig, V., Albina, E., Depner, K., Ferrari, G., Guberti, V. \& Vassant, J. (1999) Classical Swine Fever in Wild Boar. Document XXIV/B3/R09/1999. European Commission.

Mollema, L., de Jong, M.C.M. \& Van Boven, M. (2005) Prolonged persistence of bovine herpesvirus in small cattle herds: a model-based analysis. Epidemiology and Infection, 133, 137-148.

Mollison, D. \& Levin, S.A. (1995) Spatial dynamics of parasitism. In: Ecology of Infectious Diseases in Natural Populations (Ed. by B.T. Grenfell \& A.P. Dobson), pp. 384-398. Cambridge University Press, Cambridge, UK.

Moormann, R.J.M., Bouma, A., Kramps, J.A., Terpstra, C. \& De Smit, H.J. (2000) Development of a classical swine fever subunit marker vaccine and companion diagnostic test. Veterinary Microbiology, 73, 209219.

Morgan, E.R., Milner-Gulland, E.J., Torgerson, P.R. \& Medley, G.F. (2004) Ruminating on complexity: macroparasites of wildlife and livestock. Trends in Ecology and Evolution, 19, 181-188.

Narita, M., Kawashima, K., Kimura, K., Mikami, O., Shibahara, T., Yamada, S. \& Sakoda, Y. (2000) Comparative immunohistopathology in pigs infected with highly virulent or less virulent strains of hog cholera virus. Veterinary Pathology, 37, 402-408.

Okarma, H., Jedrzejewska, B., Jedrzejewski, W., Krasinski, Z. \& Milkowski, L. (1995) The roles of predation, snow cover, acorn crop, and man-related factors on ungulate mortality in Bialowieza Primeval Forest, Poland. Acta Theriologica, 40, 197-217.

Paton, D.J. \& Greiser-Wilke, I. (2003) Classical swine fever - an update. Research in Veterinary Science, 75 , 169-178.

Paton, D.J., McGoldrick, A., Greiser-Wilke, I., Parchariyanon, S., Song, J.-Y., Liou, P.P., Stadejek, T., Lowings, J.P., Björklund, H. \& Belak, S. (2000) Genetic typing of classical swine fever virus. Veterinary Microbiology, 73, 137-157.

Plateau, E., Vannier, P. \& Tillon, J.P. (1980) Experimental study of a mild virulence strain of hog cholera: individual variations and horizontal transmission. Zentralblad fur Veterinarmedicine B, 27, 650-657.

Ribbens, S., Dewulf, J., Koenen, F., Laevens, H. \& de Kruif, A. (2004a) Transmission of classical swine fever. A review. Veterinary Quarterly, 26, 146-155.

Ribbens, S., Dewulf, J., Koenen, F., Laevens, H., Mintiens, K. \& de Kruif, A. (2004b) An experimental infection (II) to investigate the importance of indirect classical swine fever virus transmission by excretions and secretions of infected weaner pigs. Journal of Veterinary Medicine B, 51, 438-442.

Rossi, S., Artois, M., Pontier, D., Cruciere, C., Hars, J., Barrat, J., Pacholek, X. \& Fromont, E. (2005a) Long-term monitoring of classical swine fever in wild boar (Sus scrofa sp.) using serological data. Veterinary Research, 36, 27-42.

Rossi, S., Fromont, E., Pontier, D., Cruciere, C., Hars, J., Barrat, J., Pacholek, X. \& Artois, M. (2005b) Incidence and persistence of classical swine fever in free-ranging wild boar (Sus scrofa). Epidemiology and Infection, 133, 559-568.

Saez-Royuela, C. \& Telleria, J.L. (1986) The increased population of the wild boar (Sus scrofa) in Europe. Mammal Review, 16, 97-101.

de Smit, A.J., Bouma, A., Terpstra, C. \& Van Oirschot, J.T. (1999) Transmission of classical swine fever virus by artificial insemination. Veterinary Microbiology, 67, 239-249.

Smith, G.C. \& Harris, S. (1989) The control of rabies in urban fox populations. In: Mammals as Pests (Ed. by R.J. Putman), pp. 209-224. Chapman \& Hall, London.

Smith, G.C., Cheeseman, C.L., Wilkinson, D. \& Clifton-Hadley, R.S. (2001) A model of bovine tuberculosis in the badger Meles meles: the inclusion of cattle and the use of a live test. Journal of Applied Ecology, 38, 520-535.

Sodeikat, G. \& Pohlmeyer, K. (2002) Temporary home range modifications of wild boar family groups (Sus scrofa L.) caused by drive hunts in Lower Saxony (Germany). Zeitschrift für Jagdwissenschaft, 48, 161-166.

Sterner, R.T. \& Smith, G.C. (2006) Modelling wildlife rabies: transmission, economics, and conservation. Biological Conservation, 131, 163-179.

Suradhat, S. \& Damrongwatanapokin, S. (2003) The influence of maternal immunity on the efficacy of a classical swine fever vaccine against classical swine fever virus, genogroup 2.2, infection. Veterinary Microbiology, 92, 187-194.

Swinton, J., Woolhouse, M.E.J., Begon, M.E., Dobson, A.P., Ferroglio, E., Grenfell, B.T., Guberti, V., Hails, R.S., Heesterbeek, J.A.P., Lavanzza, A., Roberts, M.G., White, P.J. \& Wilson, K. (2002) Microparasite transmission and persistence. In: The Ecology of Wildlife Diseases (Ed. by P.J. Hudson, A. Rizzoli, B.T. Grenfell, H. Heesterbeek \& A.P. Dobson), pp. 83-101. Oxford University Press, New York.

Terpstra, C. (1987) Epizootiology of swine fever. Veterinary Quarterly, 9, 1-50.

Terpstra, C. (1988) Epizootiology of hog cholera. In: Classical Swine Fever and Related Viral Infections (Ed. by B. Liess), pp. 201-216. Martinus-Nijhoff Publishing, Dordrecht. 
Truvé, J. \& Lemel, J. (2003) Timing and distance of natal dispersal for wild boar Sus scrofa in Sweden. Wildlife Biology, 9, 51-57.

Uttenthal, A., Storgaard, T., Oleksiewicz, M.B. \& de Stricker, K. (2003) Experimental infection with the Paderborn isolate of classical swine fever virus in 10-week-old pigs: determination of viral replication kinetics by quantitative RT-PCR, virus isolation and antigen ELISA. Veterinary Microbiology, 92, 197-212.

Van Oirschot, J.T. (1977) A congenital persistent swine fever infection. II. Immune response to swine fever virus and unrelated antigens. Veterinary Microbiology, 2, 133-142.

Van Oirschot, J.T. \& Terpstra, C. (1977) A congenital persistent swine fever infection. I. Clinical and virological observations. Veterinary Microbiology, 2, 121-132.

Vicente, J., Segales, J., Höfle, U., Balasch, M., Plana-Duran, J., Domingo, M. \& Gortazar, C. (2004) Epidemiological study on porcine circovirus type 2 (PCV2) infection in the European wild boar (Sus scrofa). Veterinary Research, 35, 243-253.

Vicente, J., Ruiz-Fons, F., Vidal, D., Höfle, U., Acevedo, P., Villanua, D., Fernandez-de-Mera, I.G., Martin, M.P. \& Gortazar, C. (2005) Serosurvey of Aujezsky's disease virus infection in the European wild boar in Spain. Veterinary Record, 156(13), 408-412.

White, P.J., Trout, R.C., Moss, S.R., Desai, A., Armesto, M., Forrester, N.L., Gould, E.A. \& Hudson, P.J. (2004) Epidemiology of rabbit haemorrhagic disease virus in the United Kingdom: evidence for seasonal transmission by both virulent and avirulent modes of infection. Epidemiology and Infection, 132, 555-567.

Woodroffe, R., Donnelly, C.A., Cox, D.R., Bourne, F.J., Cheeseman, C.L., Delahay, R.J., Gettinby, G., McInerney, J.P. \& Morrison, W.I. (2006) Effects of culling on badger Meles meles spatial organization: implications for the control of bovine tuberculosis. Journal of Applied Ecology, 43, 1-10.

Zanardi, G., Macchi, C., Sacchi, C. \& Rutili, D. (2003) Classical swine fever in wild boar in the Lombardy region of Italy from 1997 to 2002. Veterinary Record, 152, 461-465.

Submitted 10 February 2006; returned for revision 21 July 2006; revision accepted 18 December 2006 Editor: GSm 